\title{
Kairomonal Response of Predators to Three Pine Bast Scale Sex Pheromones
}

\author{
M. Branco • M. Lettere • J. C. Franco • A. Binazzi • H. Jactel
}

Received: 16 June 2004 / Revised: 13 July 2005

Accepted: 15 July 2005 / Published online: 23 May 2006

(C) Springer Science + Business Media, Inc. 2006

\begin{abstract}
The kairomonal activity of the sex pheromones of three pine bast scales, Matsucoccus feytaudi, Matsucoccus josephi, and Matsucoccus matsumurae, as well as a new analog of the $M$. feytaudi sex pheromone, were investigated in pine forests of France, Portugal, and Italy. The response of the maritime pine bast scale predators, Elatophilus spp. and Hemerobius stigma, was used to test the influence of trapping methods, kairomone composition, and dose. Both predators showed significant attraction to all compounds except to the sex pheromone of $M$. josephi. Significant increase in captures was observed as a function of dose, and within the studied dose range, up to $2200 \mu \mathrm{g}$, no threshold saturation limits were observed for any of the attractive compounds. Trap design and size did not significantly influence predator captures, except for high population levels of Elatophilus crassicornis, when plate traps were more efficient than delta traps. Geographic variations were found in the kairomonal responses patterns of both predators, with the $M$. matsumurae sex pheromone being more attractive to the oriental populations from Corsica and Italy, whereas the western populations in Aquitaine and Portugal were more attracted to the $M$. feytaudi sex pheromone.
\end{abstract}

\footnotetext{
M. Branco $(\square)$

Centro de Estudos Florestais,

Instituto Superior Agronomia, 1349-017 Lisbon, Portugal

e-mail: mrbranco@isa.utl.pt

M. Lettere

UPMC, Centre de Recherche de Versailles-Grignon,

INRA, RD 10, Route de Saint-Cyr, 78026 Versailles Cedex, France
}

J. C. Franco

Departamento de Protecção de Plantas e Fitoecologia,

Instituto Superior de Agronomia, 1349-017 Lisbon, Potugal

\section{A. Binazzi}

Instituto Sperimentale per la Zoologia Agraria,

12A Via di Lanciola, Cascine del Riccio, 50125 Florence, Italy

H. Jactel

Laboratory of Forest Entomology,

UMR BIOGECO, INRA, 33612 Cestas, France 
Keywords Pine bast scales $\cdot$ Matsucoccidae $\cdot$ Sex pheromone $\cdot$ Kairomone Elatophilus spp. Hemerobius stigma $\cdot$ Predators · Trap design · Dose response

\section{Introduction}

Pheromones represent one of the major components of ecologically based insect pest management (Howse et al., 1998). Effectively, the use of these semiochemicals for monitoring, mass trapping, mating disruption, or lure-and-kill has been investigated or developed during recent decades (e.g., Taschenberg et al., 1974; Brockerhoff and Suckling, 1999, Millar et al., 2002). However, although pheromones are generally viewed as environmentally sound, some practical problems regarding their safety could arise from their kairomonal activity. In effect, there is increasing evidence that these pheromones attract natural enemies (e.g., Bakke and Kvamme, 1981; Hendrichs et al., 1994; Boo et al., 1998; Millar et al., 2001; Mendel et al., 2004). This is of importance, as catching large numbers could impact negatively the densities of these beneficial insects, and potentially result in increases in pest populations. However, this aspect has not been studied in great detail to date. The analysis of response patterns by natural enemies to the different compounds can further elucidate the role of these infochemicals in the behavioral mechanisms related to kairomonal attraction, prey detection, prey preference, and functional response.

In this work, we undertook an international study to determine if there is dose response to sex pheromones of hosts by natural enemies, by using the responses of Elatophilus spp. and Hemerobius stigma, to the pheromones of three pine bast scales, Matsucoccus feytaudi Ducasse, Matsucoccus matsumurae Kuwana, and Matsucoccus josephi Bodenheimer and Harpaz, and also to a new analogue of the M. feytaudi sex pheromone. We also examined the specific responses of these natural enemies to different types of traps in order to develop an optimal trapping method to monitor or attract natural enemies of $M$. feytaudi and to evaluate the adverse effect of trapping with $M$. feytaudi pheromone on its natural enemies.

\section{Methods and Materials}

The experiments were repeated in four European regions: Aquitaine and Corsica in France, Península de Setúbal in Portugal, and Liguria in Italy. In each region, a trapping line was set up at two different sites, with traps separated by about $25 \mathrm{~m}$. At each site, we tested four compounds (synthetic sex pheromones of $M$. feytaudi, $M$. josephi, and $M$. matsumuare, as well as a new analogue of the $M$. feytaudi pheromone, Fig. 1) at four concentrations (400, 800, 1400, and $2200 \mu \mathrm{g})$, using two trap types (delta and plate) and two sticky surface areas $(15 \times 15 \mathrm{~cm}$ vs. $30 \times 30$ $\mathrm{cm}$ ), for a total of 64 traps. In addition, there were four control traps (a delta and plate trap with either a 15 or 30 trapping surface). Traps were made of white polypropylene and covered with a sticky material. The active compounds were used in the form of racemic mixtures: 56:44 EE/ZE ratio for $M$. josephi sex pheromone and 65:35 EE/ZE ratio for the other three compounds.

Pheromones were synthesized at the UPMC, INRA-Versailles. The new analogue was synthesized by using a procedure similar to that used for the synthesis 
<smiles>C/C=C/C(C)=C/C(=O)[C@H](C)CCC(=O)[C@H](C)/C=C(C)/C=C/C</smiles><smiles>C/C=C/C(C)=C/[C@@H](C)C(=O)CCCC(C)C</smiles><smiles>C/C=C/C(C)=C/[C@@H](C)C(=O)CC[C@@H](C)CC(C)C</smiles>

\section{M. josephi}

(2E, 6E, 8E)-5,7-dimethyl2,6,8-decatrien-4-one

\section{M. feytaudi}

(8E, 10E)-3,7,9-trimethyl dodecadien-6-one

\section{M. feytaudi analog}

$(8 E, 10 E)-2,7,9$ trimethyl8,10-dodecadien-6-one

\section{M. matsumurae}

$(2 E, 4 E)-4,6,10,12$-tetramethyl2,4-tridecadien-7-one

Fig. 1 Chemical structure of the four semiochemical compounds tested for attractiveness toward predator species of $M$. feytaudi

of M. matsumurae pheromone (Watanabe et al., 1997). Lures for M. feytaudi, M. feytaudi analogue, and M. matsumurae pheromones were loaded in caps of rubber septa (OD $8 \mathrm{~mm}$, purchased from Sigma-Aldrich) in France (INRA-Versailles), and those for $M$. josephi were prepared in Israel (Volcani Center).

Trials were carried out between April and May, 2000. Sticky surfaces of traps were replaced twice a week, and the lures (rubber septa) replaced every 2 wk. In all sites, we recorded the number of brown lacewing, H. stigma Stephens. We also collected predaceous bug adults: Elatophilus nigricornis Zetterstedt in France and Italy and Elatophilus crassicornis Reuter in Portugal.

Data were analyzed by ANOVA, following logarithmic of $x+1$ transformation and subject to post hoc Student-Newmann-Keuls multiple-range tests $(\alpha=0.05)$.

The M. josephi, M. feytaudi, and M. matsumurae pheromones have different relative volatiles (Dunkelblum et al., 1996). Therefore, to test lures with similar release rates, we compared the kairomonal response of the predators 400 and $800 \mu \mathrm{g}$ of M. feytaudi sex pheromone with that of 1400 and $2200 \mu \mathrm{g}$ of M. matsumurae sex pheromone. In this experiment, the data were analyzed using independent sample $t$ tests.

\section{Results}

Kairomone Composition and Dose

There was significant region $\times$ kairomone interaction for both $E$. nigricornis and $H$. stigma $[F(6,204)=10.51, P<0.001$ and $F(9,2720)=7.13 P<0.001$, respectively $]$, so separate ANOVAs were conducted for each region. In the four regions, and for both groups of predators, the two main factors kairomone type and dose were significant (Tables 1 and 2). The mean catches increased with increasing dose of all pher- 
Table 1 Analysis of variance to assess effect of trap type, trap size, kairomone type, and dose on H. stigma (Stephens) captures in four regions: Aquitaine, Corsica, P. Setúbal, and Liguria

\begin{tabular}{|c|c|c|c|c|c|c|c|c|c|}
\hline \multirow[t]{3}{*}{ Source } & \multirow[t]{3}{*}{$d f$} & \multicolumn{8}{|c|}{ Region } \\
\hline & & \multicolumn{2}{|c|}{ Corsica } & \multicolumn{2}{|c|}{ Liguria } & \multicolumn{2}{|c|}{ Aquitaine } & \multicolumn{2}{|c|}{ P. Setúbal } \\
\hline & & $F$ & $P$ & $F$ & $P$ & $F$ & $P$ & $F$ & $P$ \\
\hline Type & 1 & 0.03 & 0.857 & 5.03 & 0.028 & 0.86 & 0.356 & 1.08 & 0.303 \\
\hline Size & 1 & 0.11 & 0.739 & 0.95 & 0.332 & 0.75 & 0.388 & 0.05 & 0.830 \\
\hline Kairomone & 3 & 69.19 & $<0.001$ & 42.81 & $<0.001$ & 27.58 & $<0.001$ & 20.17 & $<0.001$ \\
\hline Dose & 3 & 4.81 & 0.004 & 7.69 & $<0.001$ & 12.43 & $<0.001$ & 3.09 & 0.033 \\
\hline Type $\times$ size & 1 & 0.15 & 0.702 & 0.81 & 0.371 & 0.04 & 0.849 & 0.01 & 0.914 \\
\hline Type $\times$ kairomone & 3 & 0.13 & 0.944 & 1.72 & 0.172 & 0.30 & 0.822 & 0.06 & 0.983 \\
\hline Size $\times$ kairomone & 3 & 0.10 & 0.962 & 0.53 & 0.665 & 0.24 & 0.868 & 0.16 & 0.924 \\
\hline Dose $\times$ kairomone & 9 & 0.80 & 0.614 & 1.74 & 0.097 & 1.76 & 0.093 & 0.10 & 1.000 \\
\hline Type $\times$ dose & 3 & 0.11 & 0.956 & 0.58 & 0.627 & 0.44 & 0.723 & 0.03 & 0.993 \\
\hline Size $\times$ dose & 3 & 0.03 & 0.993 & 0.24 & 0.869 & 0.76 & 0.520 & 0.03 & 0.993 \\
\hline Error & 68 & & & & & & & & \\
\hline
\end{tabular}

omones, except for that of $M$. josephi, which never differed from the control. The dose responses showed no clear saturation limit within the tested range (Figs. 2 and 3).

The highest Elatophilus species captures were in traps baited with the M. feytaudi pheromone, followed by the M. feytaudi analogue and M. matsumurae pheromone at all sites (Fig. 3). Similarly, in Aquitaine and Portugal populations, H. stigma were mostly attracted by $M$. feytaudi pheromone, followed by $M$. feytaudi analogue (Fig. 2). In contrast, especially at the higher doses, H. stigma from Corsica and Italy were mostly attracted by M. matsumurae pheromone (Fig. 2).

Table 2 Analysis of variance to assess effect of trap type, trap size, kairomone type, and dose on Elatophilus spp. (Reuter) captures in four regions: Aquitaine, Corsica, P. Setúbal and Liguria

\begin{tabular}{|c|c|c|c|c|c|c|c|c|c|}
\hline \multirow[t]{3}{*}{ Source } & \multirow[t]{3}{*}{$d f$} & \multicolumn{8}{|c|}{ Region } \\
\hline & & \multicolumn{2}{|c|}{ Corsica } & \multicolumn{2}{|c|}{ Liguria } & \multicolumn{2}{|c|}{ Aquitaine } & \multicolumn{2}{|c|}{ P. Setúbal } \\
\hline & & $\mathrm{F}$ & $P$ & $F$ & $P$ & $F$ & $P$ & $F$ & $P$ \\
\hline Type & 1 & 0.00 & 0.999 & 0.02 & 0.887 & 1.00 & 0.322 & 33.22 & $<0.001$ \\
\hline Size & 1 & 0.00 & 0.959 & 0.69 & 0.411 & 0.01 & 0.917 & 0.54 & 0.466 \\
\hline Kairomone & 3 & 90.27 & $<0.001$ & 63.70 & $<0.001$ & 283.20 & $<0.001$ & 303.43 & $<0.001$ \\
\hline Dose & 3 & 4.34 & 0.007 & 7.20 & $<0.001$ & 23.42 & $<0.001$ & 22.84 & $<0.001$ \\
\hline Type $\times$ size & 1 & 0.08 & 0.782 & 0.03 & 0.865 & 0.00 & 0.963 & 0.47 & 0.497 \\
\hline $\begin{array}{l}\text { Type } \times \\
\text { kairomone }\end{array}$ & 3 & 0.18 & 0.910 & 1.18 & 0.322 & 0.36 & 0.783 & 0.40 & 0.756 \\
\hline $\begin{array}{l}\text { Size } \times \\
\quad \text { kairomone }\end{array}$ & 3 & 0.08 & 0.972 & 0.35 & 0.792 & 0.45 & 0.721 & 0.11 & 0.953 \\
\hline $\begin{array}{l}\text { Dose } \times \\
\quad \text { kairomone }\end{array}$ & 9 & 0.69 & 0.719 & 0.69 & 0.712 & 2.01 & 0.052 & 1.56 & 0.146 \\
\hline Type $\times$ dose & 3 & 0.07 & 0.978 & 0.14 & 0.936 & 0.44 & 0.726 & 0.41 & 0.743 \\
\hline Size $\times$ dose & 3 & 0.05 & 0.983 & 0.60 & 0.619 & 1.22 & 0.310 & 0.33 & 0.807 \\
\hline Error & 68 & & & & & & & & \\
\hline
\end{tabular}



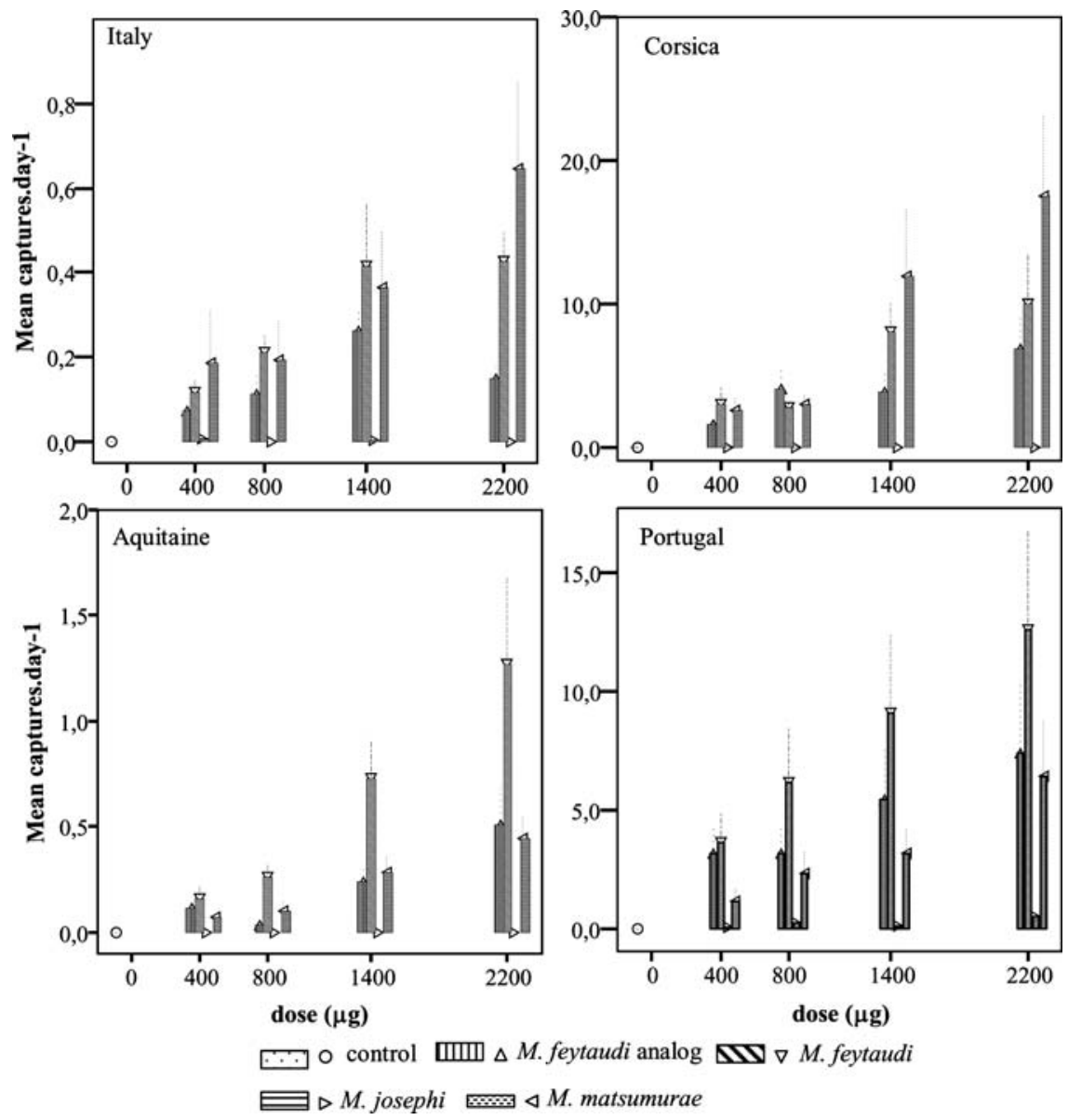

Fig. 2 Effect of kairomone and dose on H. stigma captures in Portugal, Corsica, Italy, and Aquitaine $(N=8)$, in relation to the compounds Matsucoccus feytaudi analog, M. feytaudi, M. josephi, and $M$. matsumurae

The comparison 400 and $800 \mu \mathrm{g}$ of M. feytaudi sex pheromone with 1400 and 2200 $\mu \mathrm{g}$ of $M$. matsumurae sex pheromone, gave different results depending on the region. The western populations of the brown lacewing were equally attracted to both semiochemicals, whereas the eastern populations showed a significantly higher attraction to the M. matsumurae pheromone (Table 3). Furthermore, the eastern populations of Elatophilus species showed no preference for either kairomone, whereas the western populations were more attracted to the $M$. feytaudi pheromone.

\section{Trap Size and Design}

Captures of H. stigma were higher in Corsica and Portugal than in Aquitaine and Italy (Fig. 4). In Liguria, delta traps captured significantly more brown lacewings than plate traps (Fig. 4, Table 1), whereas no differences were observed in the other three regions. As for Portugal, where the Elatophilus spp. catches were two to three times higher than in the other three regions (Fig. 5), plate traps captured more bugs 

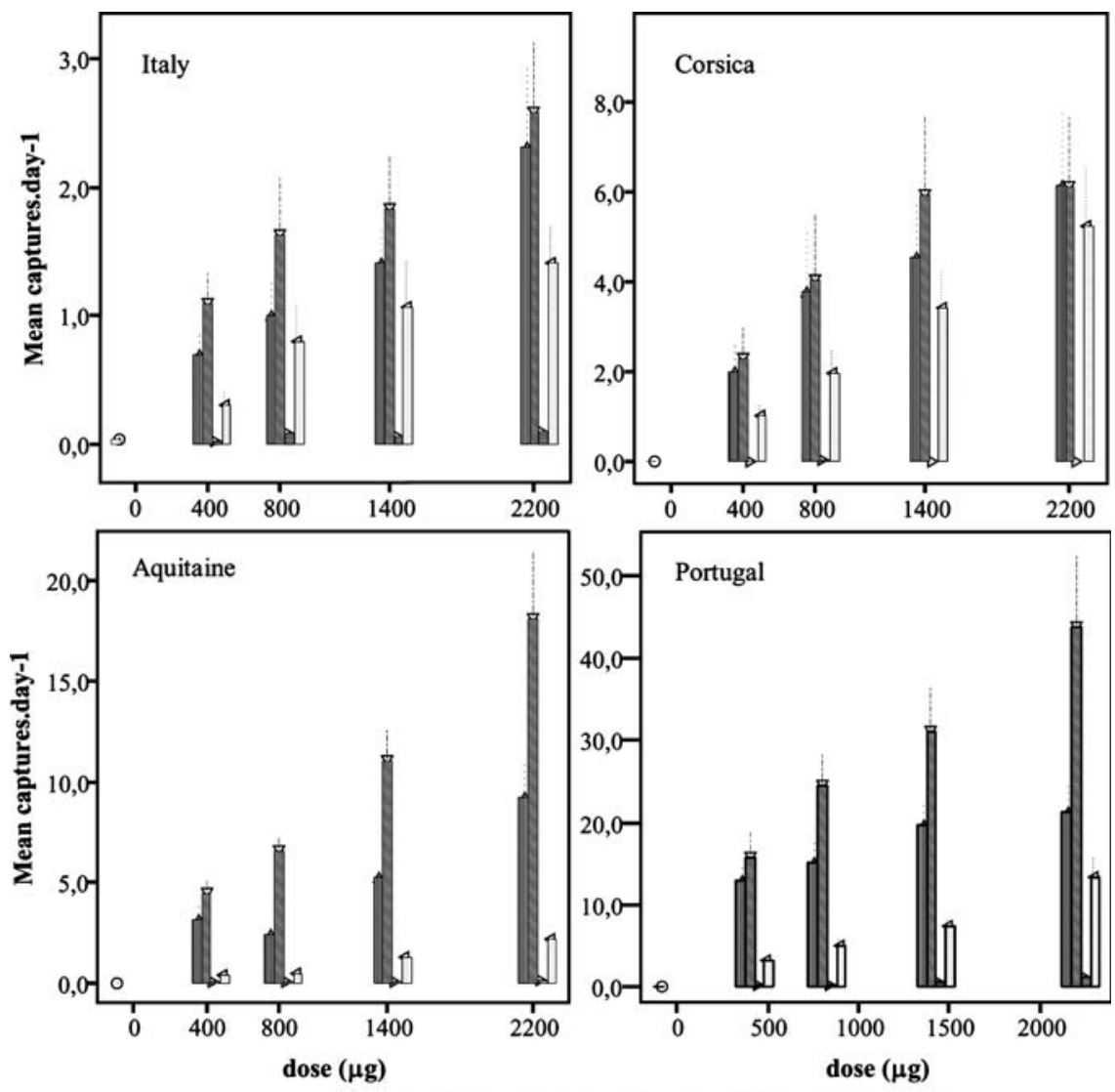

$\longrightarrow \circ$ control $\mathrm{mm} \Delta$ M. feytaudi analog $\mathbf{W} \nabla$ M. feytaudi

E $\triangleright$ M. josephi $\log \triangleleft$ M. matsumurae

Fig. 3 Effect of kairomone and dose on E. nigricornis (Aquitaine, Italy, and Corsica) and E. crassicornis (Portugal) captures $(N=8)$, in relation to the compounds Matsucoccus feytaudi analog, M. feytaudi, M. josephi, and M. matsumurae

Table 3 Comparison of kairomonal activities of $M$. feytaudi and M. matsumurae pheromones

\begin{tabular}{lllll}
\hline & Corsica & Italy & Aquitaine & Portugal \\
\hline H. stigma & & & & \\
Mm 1400 & $4.8 \pm 0.55^{\mathrm{a}}$ & $2.4 \pm 0.35$ & $1.5 \pm 0.26$ & $3.8 \pm 0.54$ \\
Mf 400 & $3.2 \pm 0.28$ & $1.6 \pm 0.21$ & $0.9 \pm 0.31$ & $3.7 \pm 0.57$ \\
Mm 2200 & $5.2 \pm 0.55^{\mathrm{a}}$ & $3.1 \pm 0.28^{\mathrm{a}}$ & $1.9 \pm 0.24$ & $4.6 \pm 0.46$ \\
Mf 800 & $3.7 \pm 0.31$ & $1.9 \pm 0.36$ & $1.5 \pm 0.24$ & $4.1 \pm 0.46$ \\
Elatophilus spp. & & & & \\
Mm 1400 & $4.1 \pm 0.34$ & $3.7 \pm 0.38$ & $3.1 \pm 0.22$ & $5.2 \pm 0.14$ \\
Mf 400 & $3.4 \pm 0.51$ & $3.7 \pm 0.24$ & $4.3 \pm 0.21^{\mathrm{a}}$ & $5.9 \pm 0.22^{\mathrm{a}}$ \\
Mm 2200 & $4.5 \pm 0.34$ & $4.3 \pm 0.21$ & $3.8 \pm 0.12$ & $5.7 \pm 0.22$ \\
Mf 800 & $4.0 \pm 0.46$ & $4.0 \pm 0.26$ & $4.8 \pm 0.16^{\mathrm{a}}$ & $6.4 \pm 0.20^{\mathrm{a}}$ \\
\end{tabular}

Values are $\log ($ mean captures per trap) \pm SE. Mm, M. matsumurae; Mf, M. feytaudi.

${ }^{\text {a }} P<0.05$; significantly different from the other treatments (independent sample $t$ test). 


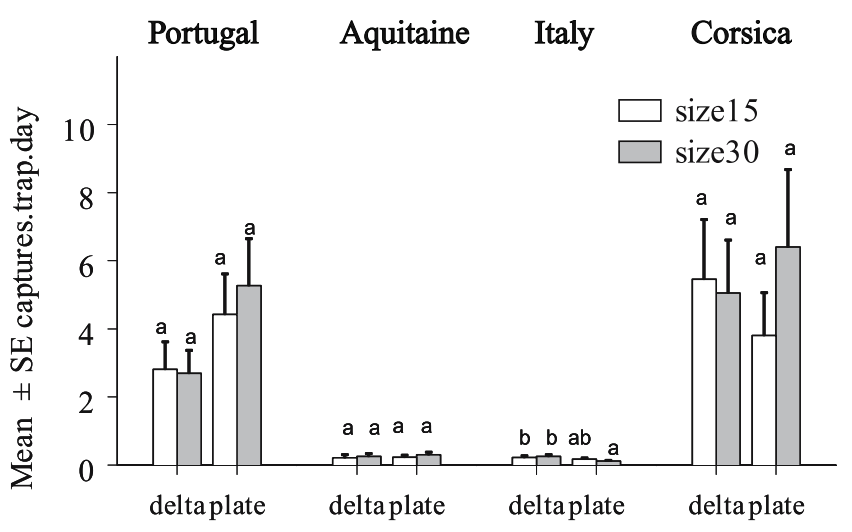

Trap type

Fig. 4 Effect of region, trap type, and trap size on the mean catches of $H$. stigma $(N=34)$. Within each site, means with the same letter are not significantly different (SNK test, $\alpha=0.05$ )

than delta traps, thus explaining the observed trap type effect for this species (Table 2). Differences caused by trap size were not significant at any site.

\section{Discussion}

The results provide new evidence that predators respond to the sex pheromones of several scale species in several different geographic locations, suggesting that they play a role in host location. This kairomonal activity was previously demonstrated in Europe (Mendel et al., 2003, 2004) and Israel, where E. hebraicus responded to the same Matsucoccus pheromones (e.g., Dunkelblum et al., 1996; Mendel et al., 1997, 2003). Pine bast scales occupy an inconspicuous location under the bark of the trunk where they feed on the phloem, and in their native environment they generally

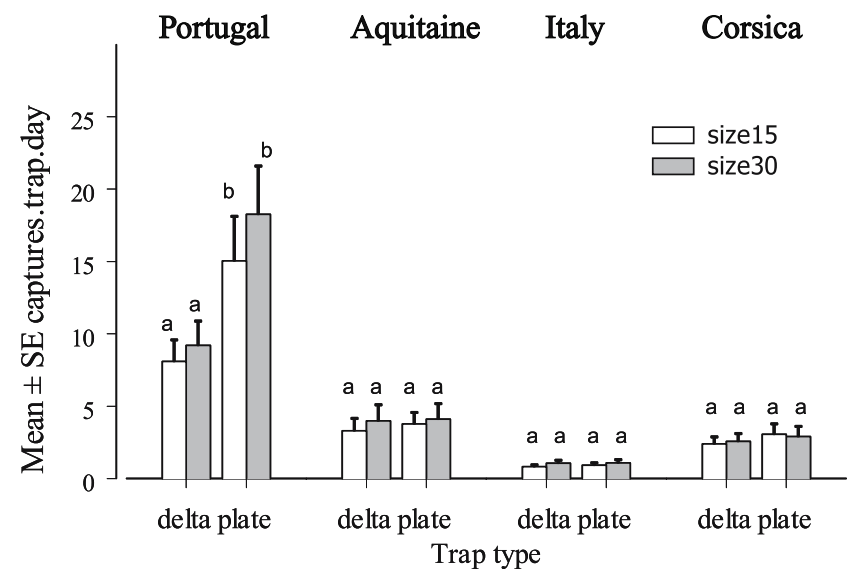

Fig. 5 Effect of region, trap type, and trap size on the mean catches of E. nigricornis (Aquitaine, Italy, and Corsica) and E. crassicornis (Portugal) $(N=34)$. Within each site, means with the same letter are not significantly different (SNK test, $\alpha=0.05$ ) 
occur in extremely low densities. Therefore, the use of the host sex pheromone would provide a reliable cue to locate prey, and the fact that they respond to the pheromones of several different scales would improve their ability to locate different host species. Predators require higher concentrations to locate the pheromone source than male pine scales, suggesting that scales may only be extensively exploited when densities are abundant enough to sustain natural enemy populations. However, the high kairomonal response of predators suggests that sex pheromone may also be used to draw natural enemies into the habitat and increase the local population of natural enemies. Further studies are needed to evaluate this possibility.

There are several nonmutually exclusive explanations for the observed intersite differences that are noted above: (i) the effect of prevailing climate on both the effectiveness/longevity of lures, as well as the behavior of the target species, (ii) the actual population densities of prey/predator populations, (iii) the relative importance of the scales as prey to these predators in each habitat, and (iv) the time that prey and predators have been in association at the different sites (Jonsson and Anderbrant, 1993; Sharov et al., 1996; Mendel et al., 1997; Krips et al., 1999). Although several examples of different geographic variation in intraspecific sex pheromones have been reported (McElfresh and Millar, 2001; Anderbrant et al., 2000; El Sayed et al., 2003), we believe that the marked differences in response of both $H$. stigma and Elatophilus spp. to different host pheromones is the first example of geographic variation in response to kairomones. These differences are possibly related to the fact that the western regions correspond to the original geographical range of $M$. feytaudi, whereas this species was only introduced into Italy and Corsica in the 1970s and 1990s, respectively (Covassi and Binazzi, 1992; Jactel et al., 1998; Burban et al., 1999). Prior to the introduction of M. feytaudi, M. pini was the only pine bast scale present in these eastern regions (Rieux, 1976; Tranfaglia et al., 1985). The sex pheromone of $M$. pini is not known, but our results suggest that it may resemble the sex pheromone of $M$. matsumurae. This is also consistent with the observation that Sympherobius fuscescens, another potential predator of $M$. pini in the eastern areas, also responded to the sex pheromone of $M$. matsumurae but not to that of $M$. feytaudi (Mendel et al., 2004). The observation that the predators of $M$. pini responded to the $M$. matsumurae pheromone emphasizes the need to clarify the taxonomic status of these two species, as suggested by Kosztarab and Kozár (1988).

Dunkelblum et al. (2000) reported that the species specificity of the pheromone was dependent on the structure of the side chain, whereas the kairomonal effect was dependent on the ketodiene moiety. However, as all compounds tested in this study had a common ketodiene moiety yet differed markedly in kairomonal activity, this indicates that changes in the side chain also affect the response of natural enemies.

There are significantly different dose-dependent responses by scale predators. When sex pheromones are used as a pest management strategy, then the potential negative effects on the populations of natural enemies must take this into consideration when determining the most effective dose to use. Furthermore, no saturation level was observed by predators over the dose range tested, which contrasts with the observed response of $M$. feytaudi males to increasing dose of sex pheromone (Branco et al., 2004). The present results indicate that generally the size and type of trap did not influence efficiency, except for large plate traps, which 
caught more E. crassicornis when there were high densities of this predator. A preference for vertical objects, as observed elsewhere among other groups of insects that use trees for shelter or feeding (e.g., Willis et al., 1994; Gross et al., 2001), may explain this result.

In summary, the present study provides information on the kairomonal responses of these entomophagous insects that could be useful in the pest management strategies against the pine bast scale. Additional research is required to determine the relative importance of biotic and abiotic factors affecting the responses of natural enemies to scale pheromones, and how these may differ at different geographic locations.

Acknowledgments We are grateful for the field assistance of Elsa Borges, Manuel Cariano, and Pierre Menassieu. We thank the referees and Zvi Mendel (Volcani Center) for critical comments on earlier versions. The work was partly supported by the Commission of the European Communities (FAIR) within the specific RTD program, Contract CT97-3440, "PHOCUS." The present paper does not necessarily reflect the Commission's views and in no way anticipates the Commission's future policy on the matter.

\section{References}

Anderbrant, O., Lofovist, J., Hogberg, H. E., Hedenstrom, E., Baldassari, N., Baronio, P., Kolmakova, G., Lyons, B., Naito, T., Odinokov, V., Simandl, J., Supatashvili, A., TAI, A., and TOURIANOV, R. 2000. Geographic variation in the field response of male European pine sawflies, Neodiprion sertifer, to different pheromone stereoisomers and esters. Entomol. Exp. Appl. 95:229-239.

BAKKE, A. and KVAMmE, T. 1981. Kairomone response in Thanasimus predators to pheromone components of Ips typographus. J. Chem. Ecol. 7:305-312.

Boo, K. S., Chung, I. B., Han, K. S., Pickett, J. A., and Wadhams, L. J. 1998. Response of the lacewing Chrysopa cognita to pheromone of its aphid prey. J. Chem. Ecol. 24:631-643.

Branco, M., Jactel, H., Silva, E. B., BinazZi, A., and Mendel, Z. 2004. Effect of trap design, trap size and pheromone dose on male capture of two pine bast scales species (Hemiptera: Matsucoccidae): implications for monitoring and for mass-trapping. Agric. For. Entomol. 6:233239.

Brockerhoff, E. G. and Suckling, D. M. 1999. Development of an attracticide against light brown apple moth (Lepidoptera: Tortricidae). J. Econ. Entomol. 92:853-859.

Burban, C., Petit, R. J., CARCrefF, E., and Jactel, H. 1999. Rangewide variation of the maritime pine bast scale Matsucoccus feytaudi Duc. (Homoptera: Matsucoccidae) in relation to the genetic structure of its host. Mol. Ecol. 8:1593-1602.

Covassi, M. and BinAZZI, A. 1992. Primi focolai di Matsucoccus feytaudi Duc. nella Liguria orientale (Homoptera: Margarodidae). Redia 75:453-466.

Dunkelblum, E., Mendel, Z., Gries, G., Gries, R., Zegelman, L., Hassner, A., and Mori, K. 1996. Antennal response and field attraction of the predator Elatophilus hebraicus (Hemiptera: Anthocoridae) to sex pheromones and analogues of the three Matsucoccus spp. (Homoptera: Matsucoccidae). Bioorg. Med. Chem. 4:489-494.

Dunkelblum, E., Harel, M., Assael, F., Mori, K., and Mendel, Z. 2000. Specificity of pheromonal and kairomonal response of the Israeli pine bast scale Matsucoccus josephi and its predator Elatophilus hebraicus. J. Chem. Ecol. 26:1649-1657.

El SAyed, A. M., Delisle, J., Lury, N. DE, Gut, L. J., JudD, G. J. R., Legrand, S., Reissig, W. H., Roelofs, W. L., Unelius, C. R., Trimble, R. M., and De LuRY, N. 2003. Geographic variation in pheromone chemistry, antennal electrophysiology, and pheromone-mediated trap catch of North American populations of the oblique banded leafroller. Environ. Entomol. 32:470-476.

Gross, S., Dunkelblum, E., Assael, F., Harel, M., Zada, A., and Mendel, Z. 2001. 
Characterization of the performance of pheromone traps as a basis for the management of the citrus mealybug in citrus grove. Boll. Zool. Agrar. Bachic. Ser. II 33:283-295.

Hendrichs, J., KATsOyannos, B. I., WornoAyporn, V., and Hendrichs, M. A. 1994. Odourmediated foraging by yellowjacket wasps (Hymenoptera: Vespidae): predation on leks of pheromone-calling Mediterranean fruit fly males (Diptera: Tephritidae). Oecologia 99:88-94.

Howse, P., Stevens, I., and Jones, O. 1998. Insect Pheromones and Their Use in Pest Management. Chapman \& Hall, London.

Jactel, H., Menassieu, P., Ceria, A., Burban, C., Regad, J., Normand, S., and Carcreff, E. 1998. Une pullulation de la cochenille Matsucoccus feytaudi provoque un début de dépérissement du pin maritime en Corse. Rev. For. Fr. 50:33-45.

JONSSON, P. and ANDERBRANT, O. 1993. Weather factors influencing catch of Neodiprion sertifer (Hymenoptera: Diprionidae) in pheromone traps. Environ. Entomol. 22:445-452.

Kosztarab, M. and KozÁr, F. 1988. Scale Insects of Central Europe. Dr. W. Junk Publishers, Dordrecht.

Krips, O. E., Willems, P. E. L., Gols, R., Posthumus, M. A., and Dicke, M. 1999. The response of Phytoseiulus persimilis to spider mite-induced volatiles from gerbera: influence of starvation and experience. J. Chem. Ecol. 25:2623-2641.

MCELfResh, J. S. and MillaR, J. G. 2001. Geographic variation in the pheromone system of the saturniid moth Hemileuca eglanterina. Ecology 82:3505-3518.

Mendel, Z., Adar, K., Nestel, D., and Dunkelblum, E. 1997. Sex pheromone as a tool for the study of population trends of the predator of a scale insect and for the identification of potential predators for biological control. IOBC/WPRS Bull. 20:231-240.

Mendel, Z., Dunkelblum, E., Branco, M., Franco, J. C., Kurosawa, S., and Mori, K. 2003. Synthesis and structure-activity relationship of diene modified analogs of Matsucoccus sex pheromones. Naturwissenschaften. 90(7):313-317.

Mendel, Z., Assael, F., and Dunkelblum, E. 2004. Kairomonal attraction of predatory bugs (Heteroptera: Anthocoridae) and brown lacewings (Neuroptera: Hemerobiidae) to sex pheromones of Matsucoccus species (Hemiptera: Matsucoccidae). Biol. Control 30:134-140.

Millar, J. G., Rice, R. E., Steffan, S. A., DaAne, K. M., Cullen, E., and Zalom, F. G. 2001. Attraction of female digger wasps, Astata occidentalis Cresson (Hymenoptera: Sphecidae) to the sex pheromone of the stink bug Thyanta pallidovirens (Hemiptera: Pentatomidae). Pan-Pac. Entomol. 77:244-248.

Millar, J. G., DaAne, K. M., McElfresh, J. S., Moreira, J. A., Malakar Kuenen, R., Guillen, M., and BENTLEY, W. J. 2002. Development and optimization of methods for using sex pheromone for monitoring the mealybug Planococcus ficus (Homoptera: Pseudococcidae) in California vineyards. J. Econ. Entomol. 95:706-714.

RIEUX, R. 1976. Matsucoccus pini Green (1925) (Homoptera, Margarodidae) dans de sud-est de la France. Variations intraspecifiques. Comparaison avec des especes les plus proches. Ann. Zool. Ecol. Anim. 8:231-263.

Sharov, A. A., Liebhold, A. M., and Roberts, E. A. 1996. Spatial variation among counts of gypsy moths (Lepidoptera: Lymantriidae) in pheromone-baited traps at expanding population fronts. Environ. Entomol. 25:1312-1320.

TAschenberG, E. F., CARde, R. T., and Roelofs, W. L. 1974. Sex pheromone mass trapping and mating disruption for control of redbanded leafroller and grape berry moths in vineyards. Environ. Entomol. 3:239-242.

Tranfaglia, A., Pellizzari, G., and Marotta, S. 1985. Reperti su Coccoidea della fauna italiana. Atti XIV Congresso Nazionale Italiano di Entomologia. Erice, 28 May-1 June: 119126.

Watanabe, H., Watanabe, T., Kitahara, T., and Mori, K. 1997. Concise synthesis of a racemic and diastereomeric mixture of the sex pheromones of Matsucoccus pine scales. Biosci. Biotechnol. Biochem. 61:127-130.

Willis, M. A., DAVID, C. T., Murlis, J., and CARdÉ, R. T. 1994. Effects of pheromone plume structure and visual stimuli on the pheromone-modulated upwind flight of male gypsy moth (Lymantria dispar) in a forest. J. Insect Behav. 7:385-409. 